\title{
Şehirlerarası Karayolu Ulaştırma Hizmetlerinde Otobüs Firmalarına Yönelik Hizmet Kalitesi Algısı: Afyon Kocatepe Üniversitesi Öğrencileri Üzerine Bir Araştırma
}

$\ddot{O} z$ Şerif Ahmet DEMIRDAĞ $\breve{G}^{*}$ Elbeyi PELIT ${ }^{\dagger}$

Bu araştırmanın amacı, karayolu ulaşımında otobüs işletmelerini sıkça kullanan öğrencilerin hizmet kalitesi algısını ortaya koymaktır. Karayolu taşıma şirketlerinde önemli bir paya sahip olan otobüs firmalarının yoğun rekabet ortamında kaliteli bir hizmet vermesi rekabet üstünlüğ̈̈ açısından oldukça önemlidir. Bu noktada, Türkiye nüfusunun yaklaşık \%10'unu oluşturan öğrencilerin karayolu ulaşımındaki hizmet kalitesi algısını belirlemenin ve bu doğrultuda öneriler geliştirmenin gerekli olduğu düşünülmekte, ayrıca sunulan önerilerin firmaların iyileştirme ve geliştirme politikalarına katkı sağlayacağı amaçlanmaktadır. Bu doğrultuda, araştırmada kullanılan veriler Afyon Kocatepe Üniversitesinde farklı fakültelerde eğitim gören 723 öğrenci üzerinde anket tekniği uygulanarak toplanmıştır. Söz konusu anketler 2019/2020 EğitimÖğretim yılı akademik takvime göre vize sınavlarının bitiş tarihi olan 15 Kasım 2019 ile 29 Kasım 2019 tarihleri arasında tesadüfi olarak otogarda bulunan öğrenciler üzerinde uygulanmıştır. Genel olarak katılımcıların otobüs firmalarına yönelik hizmet kalitesi algıları orta düzeyin biraz üzerinde bulunmuştur. Hizmetleri kullanan üniversite öğrencilerinin hizmet kalitesi algısında en yüksek puana sahip olan faktörler "rezervasyon ve bilet satın alma işlemleri" ve "mola" iken, en düşük olan faktör ise "şehir içi servis araçları ve görevlileri" olduğu sonucuna ulaşılmıştır. Ayrıca, katılımcıların demografik özellikleri açısından hizmet kalitesi algılarının farklılık gösterip göstermediği test edilmiş ve sadece ortalama aylık harcama açısından güvenirlik boyutunda anlamlı farklılıklar olduğu tespit edilmiştir.

Anahtar Kelimeler: Karayolu Ulaşım İşletmeleri, Hizmet Kalitesi.

\section{Perception of Service Quality for Bus Companies in Intercity Road Transport Services: A Study on Afyon Kocatepe University Students Abstract}

The purpose of this research is to determine the perception of service quality of students who frequently use bus companies in road transportation. It is very important in terms of competitive advantage that bus companies, which have an important share in road transport companies, provide a quality service in an intense competitive environment. At this point, it is considered necessary to determine the perception of service quality in road transportation of students who occurred approximately $10 \%$ of Turkey's population, and to present suggestions accordingly; it is also aimed that the suggestions presented will contribute to the improvement and development policies of companies. For the purpose of the research, the data used in the research were collected by applying a survey technique on 723 students studying in different faculties at Afyon Kocatepe University. The questionnaires were applied to the students who were randomly at the bus station between the dates of 15th of November, and 29th of November 2019, which are the end dates of the midterm exams according to the academic calendar 2019/2020 academic year. In general, the service quality perceptions of the participants towards bus companies were slightly above the medium level. It was concluded that the factors with the highest scores in the perception of service quality of university students who use the services are "reservation and ticket purchase transactions" and "stopover", while the lowest factor is "city shuttle vehicles and staff". In addition, it was also tested whether the perceptions of service quality differed in terms of demographic characteristics of the participants and it was determined that there were significant differences in the reliability dimension only in terms of average monthly expenditure.

Keywords: Road Transportation Companies, Service Quality, Afyon Kocatepe University.

Geliş/Received: 01.30 .2021

Kabul/Accepted: 23.06 .2021

* Bu çalışmanın planlanması, gerçekleştirilmesi ve sonuçlandırılması süreçlerinde "Yükseköğretim Kurumları Bilimsel Araştırma ve Yayın Etiği Yönergesi”nde belirtilen etik kurallar dikkate alınmıştır. Çalışmada kullanılan veriler 2019 yılının Kasım ayına ait olduğu için etik kurul raporu gerekmemektedir.

\footnotetext{
* Dr. Öğr. Üyesi, Giresun Üniversitesi, Bulancak Kadir Karabaş Uygulamalı Bilimler Yüksekokulu, Turizm İşletmeciliği Bölümü, Bulancak-Giresun, Türkiye, serif.demirdag@ giresun.edu.tr, Tel: 00904543101890 (1893) ORCID ID: orcid.org/0000-0003-4317-5727

+ Prof. Dr., Afyon Kocatepe Üniversitesi, Turizm Fakültesi, Turizm Rehberliği Bölümü, Afyonkarahisar, Türkiye, elbeyipelit@aku.edu.tr, ORCID ID: orcid.org/0000-0002-6418-801X

(Makale türü: Araştırma makalesi)
} 


\section{Giriş}

İnsanlar, çağlar boyunca farklı sebeplerle farklı şekillerde seyahat etme ihtiyacı duymuşlardır. İçinde yaşanılan çağa göre kimi insanlar avlanmak için, kimileri ticaret için, kimileri dini vecibeleri yerine getirmek için, kimileri keşif için, kimileri eğitim için, kimileri ise tamamen tanımak-öğrenmek için seyahat etmiştir. Özellikle 18. ve 19. yüzyıllarda yeni buluşların ve makineleşmenin yaşandığı Sanayi Devrimi ile birlikte insanların iş ve özel yaşamlarında köklü değişiklikler yaşanmaya başlamıştır. Söz konusu süreçte yaşanan teknolojik gelişmeler, ulaşım araçları üzerinde de olumlu yönde oldukça etkili olmuştur. Sanayi Devrimi'nde üretim için gerekli olan buharlı makinaların yanı sıra, aynı dönemin önemli sembollerinden olan buharlı tren ve gemiler hem taşımacılıkta hem de ulaşımda büyük rol oynamıştır. Yeni buluşlar ve teknolojinin daha ileri boyutlara taşınmasıyla birlikte daha konforlu, daha hızlı ve modern ulaşım araçları (hızlı tren, uçak, gemi, otomobil, otobüs vb.) üretilmeye başlanmıştır. Modern çağda bütün ulaşım araçlarının kullanılmasıyla birlikte en fazla kullanılan ve tercih edilen ulaşım türü ise karayolları ulaşımı olmuştur. Ulaşım kolaylığı, bütçeye uygunluğu ve konforu açısından karayolları ulaşımı ile kara parçaları üzerinde mümkün olan her yere ulaşım sağlanabilmektedir. Bu kapsamda, genellikle üniversite eğitimini ailelerinin ikameti dışında farklı bir şehirde alan öğrenciler de çoğunlukla ulaşım tercihini karayolu ulaşım firmaları yönünde yapmaktadır. Yükseköğretim Kurumu'nun Bilgi Yönetim Sistemi resmi internet sitesindeki Yükseköğretim İstatistiklerine göre, 2019-2020 öğretim yılında Türkiye'de önlisans, lisans, yüksek lisans ve doktora düzeyinde eğitim gören toplam öğrenci sayısının 7940133 oluğu belirtilmektedir (YÖK İstatistik, 2020). Türkiye toplam nüfusunun nerdeyse $\% 10$ 'unu oluşturan bu oran, sektörün hareketliliği ve dinamiği için oldukça önemli bir orandır. Özellikle sömestr aralarında, dinî bayramlarda ve kısmen resmî tatillerde öğrencilerin belirli süreliğine asıl ikametlerine dönme arzularıyla karayolu ulaşımında -özellikle de otobüs firmalarında- yoğunlukların yaşandığı bilinmektedir. Farklı kesimler tarafindan fazlasıyla tercih edilen karayolu ulaşımında önemli bir sektör olan otobüs taşımacılı̆̆ firmaları, talep karşısında en iyi hizmeti sunarak rekabet üstünlüğü elde etmeye çalışmaktadır. Bu noktada, otobüs taşımacılığ firmalarının müşteri portföyünde önemli bir paya sahip olan üniversite öğrencilerinin şehirlerarası kara ulaşımında faaliyet gösteren otobüs firmalarına yönelik hizmet kalitesi algılarını belirlemek ve bu konuda ilgili taraflar için öneriler geliştirmek bu araştırmanın çıkış noktasını oluşturmuştur. Karayolu ulaşımında otobüs firmalarını sıklıkla tercih eden öğrencilerin firmalara yönelik hizmet kalitesi algılarını belirlemek amacıyla farklı bölümlerde okuyan Afyon Kocatepe Üniversitesi öğrencilerine anket tekniği uygulanmış 
ve böylelikle araştırmada kullanılan veriler elde edilmiştir. Araştırma verilerinin analiz edilmesinden elde edilen bulgular doğrultusunda ilgili taraflar için önerilerde bulunulmuştur.

\section{Literatür Taraması}

Çoğu işletme, hizmet kalitesi ve tüketici memnuniyetine büyük oranda önem vermektedir (Iacobicci, vd. 1995). Çünkü hizmet kalitesinin, işletmelerin verimliliği, kârlılığı, müşteri memnuniyeti ve buna bağlı olarak tercih edilirliği üzerinde etkili olduğu söylenebilir. Hizmet kalitesi kavramına geçmeden önce, bu sözcük öbeğini oluşturan "hizmet" ve "kalite" kavramlarının ne anlama geldiğinin belirtilmesi yerinde olacaktır. Farklı tanımların önemli kriterlerini birleştiren Güçer vd. (2017, s. 456), hizmet kavramını "maddi bir nitelik taşımayan, elle tutulamayan, insan y a da makinalar aracılığlyla sunulan ve alan tarafin bir fayda sağladiğı faaliyetler ve faydalar bütünü" olarak tanımlamıştır. Kalite ise "tüketicilerin ya da kullanıcıların mal ve/veya hizmetlere yönelik yargısı olup, beklenti ve gereksinimlerinin karşılanmasına yönelik inançlarının ölçüsü̈' olarak tanımlanmaktadır (Tavmergen, 2002, s. 27). Ancak kalite algısı, tüketiciden tüketiciye göre farklı anlamlar taşıyabilmektedir. Örneğin kalite, kimi tüketiciler için ürünlerin özellikleri, sağlamlığı, amaca uygunluğu olarak değerlendirilirken, kimi tüketiciler için de fiyatının yüksek olması ile değerlendirilmektedir (Başanbaş, 2013). Tüketicilerin tatmini sağlamak üzere yönetilen iş ve iyileştirme süreçleri olarak betimlenen hizmet kalitesi (Gržinić, 2007), tüketicilerin hizmetleri satın aldıktan ya da kullandıktan sonra tüketiciler üzerinde ortaya çıkardığı duygular olup, hizmetlerden hangi düzeyde tatmin olduklarını göstermektedir (Çiçek ve Doğan, 2009). Okumuş ve Duygun (2008)'a göre hizmet kalitesi, tüketici beklentilerinin karşıllanmasına yönelik verilen en mükemmel hizmet sunumudur. Hernon ve Nitecki (2001, s. 690), hizmet kalitesinin tanımlanabilmesi için en az "mükemmellik (excellence)", "değer (value)", "şartlara uygunluk (conformance to specifications)" ve "beklentilerin karşılanması ve/veya üstünde tutulması (meeting and/or exceeding expectations)" terimlerini içermesi gerektiğini ifade etmektedir. Benzer bir şekilde Parasuraman vd. (1985, s.48), işletmelerin verimliliğini sağlayacak olan hizmet kalitesinin; "erişim (access)", "iletişim (communication)", "yeterlilik (competence)", "nezaket (courtesy)", "güvenilirlik (credibility)", "dayanıklılık (reliability)", "sorumluluk (responsiveness)", "güvenlik (security)", "anlayış (understanding)" ve "somut şeyler (tangibles)" olmak üzere on belirleyicisinin olduğunu belirtmektedir. Bu açıklamalar ışığında, tüketicilerin algısına göre aldıkları hizmetlerde söz konusu bu belirleyicilerin tamamı ya da bir kısmı gerçekleştiğinde hizmet kalitesinden bahsetmenin mümkün olacağı yorumu yapılabilir. Araştırmanın temel konusu olan, karayolu otobüs taşımacılı̆̆ işletmeleri, teknolojinin ilerlemesiyle birlikte sundukları hizmetlerin kalitesini artırmaya ve böylelikle rekabet avantajını ellerinde tutmaya çalışmaktadır.

Ulaştırma ve Altyap1 Bakanlığ1 Karayolları Genel Müdürlüğü (2020) resmî internet sayfasında yer alan bilgilere göre, Türkiye'de 1923 yılında 13.900 km'si stabilize şose ve 4.450 
km'si toprak olmak üzere, toplam $18.350 \mathrm{~km}$ yol ve 94 köprü olduğu belirtilmektedir. Bununla birlikte Cumhuriyetin ilk yıllarında ulaşımda, dönemin en çağdaş teknolojisi olan demiryolu yapımının ağırlık kazandığı, ancak bir süre sonra demiryolunun tek başına yeterli olmadığı, sistemin ucundaki ulaşım için karayoluna ihtiyaç olduğu görülerek, 1929 yılında Nafia Vekaleti (Bayındırlık Bakanlığı) içinde Şose ve Köprüler Reisliği kurularak çıkarılan yol kanunu ile karayolu yapım çalışmalarına hız verildiği de ifade edilmektedir. Aynı resmî internet kaynağında geçen bilgiye göre, söz konusu dönemden günümüze kadar geçen süre içinde yapılan çalışmalar neticesinde, Karayolları Genel Müdürlüğü'nün Nisan 2020 itibarıla 3.095 km (\%5) otoyol olmak üzere toplamda $68.266 \mathrm{~km}$ yol ağına sahip olduğu görülmektedir (Ulaştırma ve Altyapı Bakanlığı Karayolları Genel Müdürlüğü, 2020). Bu gelişmeler, Türkiye'de diğer ulaşım sistemlerine oranla karayolu ulaşımını daha cazip hale getirmiş ve birçok insan tarafından daha fazla tercih edilir duruma gelmesine temel oluşturmuştur. Toplu ulaşım araçlarından özellikle otobüs taşımacılığı göz önüne alındığında, ilk olarak 1926 yılında ehliyetini aldıktan sonra kendi imkanlarıyla üstünü ahşaptan tentelerle çevrelediği otomobiliyle Bursa ve Karaköy arasında ilk seferlere başlayan Kâmil Koç, 1927 yılında araç ve şoför sayısını yükselterek aynı güzergâhta seferlerini sürdürmeye devam etmiştir (Kâmil Koç, 2020). Belirtildiği üzere, ulaşım ağının altyapı olanaklarının artması ve teknolojinin de katkısıyla birlikte hem bölgesel olarak şehir içi hem ilçeler arası hem de şehirlerarası otobüs taşımacılığı günümüzde çok farklı boyutlara ulaşmıştır. Özellikle şehirlerarası yolculuklar için neredeyse her otobüs işletmesi yolcularının güvenliği, rahatı, yolculuk boyunca iletişim ve eğlence gibi olanaklara sahip olmaları için kendi aralarında gizli bir yarış başlatmıştır. Bu noktada her işletmenin rekabet üstünlüğü elde edebilmek adına sunduğu avantaj ve hizmetler tüketicilerin hizmet kalitesi algısı ile doğru orantılıdır. Sözü edilen konu ile ilgili daha önce karayolu ulaşımı ve tüketicilerin hizmet kalitesi algıları üzerine yapılan çok sayıdaki yerli akademik çalışmaların sonuçları ile 2019 yılının sonunda yapılan bu çalışmanın arasındaki benzerlikler ve farklılıklar ortaya konmaya çalışılmıştır.

Otobüs firmalarının pazarlama stratejileri üzerine Kahramanmaraş’ta Tan ve Bektaş (2002) tarafından yapılan araştırmanın sonucuna göre, ikramlardaki yetersizlik, yetersiz şehir içi servisleri, durak dışı yolcu alma-indirme gibi faktörlerden dolayı tüketicilerin beklentilerinin karşılanmadığı sonucuna ulaşılmıştır. Çatı (2003) tarafından, Sivas'ta üniversite öğrencileri üzerine ulaşım hizmetlerinde hizmet kalitesinin belirlenmesine yönelik gerçekleştirilen çalışmanın sonucuna göre, araçlara fazla yolcu alınması ve personel davranışlarının olumsuzlukları tüketicilerin hizmet kalitesi algısını olumsuz yönde etkilediği tespit edilmiştir. Benzer bir şekilde, Çatı ve Yıldız (2005) tarafından şehirlerarası otobüs işletmelerinde hizmet 
kalitesinin ölçülmesine yönelik yapılan çalışmada, merkezi Sivas İli olan otobüs firmalarından hizmet satın alan müşterilerin büyük çoğunluğunun $(\% 66,3)$ genel olarak firmalardan memnun oldukları sonucuna ulaşılmıştır. Somut öğeler, müşteriyi anlamak, nezaket, güvenirlik ve istekli olmak faktörleri altında gerçekleştirilen çalışmada tüketici memnuniyeti ile en fazla ilişkinin bulunduğu faktörler ise "istekli olma" ve "güvenirlik" faktörlerinin olduğu belirtilmektedir. Duman vd. (2007) tarafından karayolu taşımacılığında hizmet kalitesi, hizmet değeri, tüketici memnuniyeti ve sadakat üzerinde Mersin'de gerçekleştirilen bir çalışmanın sonucuna göre, yazıhane-servis-terminal hizmetleri, seyahat süresinde alınan hizmetler ve mola yeri hizmetlerinin tüketici hizmet kalitesi algılarını belirlediği ifade edilmektedir. Özgüven (2008) tarafından bir otobüs firmasında hizmet pazarlaması kapsamında müşteri memnuniyeti üzerine yapılan çalışmanın sonucunda, tüketicilerin genel olarak ilgili otobüs firmasının hizmetlerinden memnun oldukları ve tekrar tercih edecekleri yönünde bulgular elde edilmiştir. Alnıaçık ve Özbek (2009), Kocaeli’nde bir otobüs firması üzerinde üniversite öğrencilerine yönelik yaptığ çalışmanın sonucunda, katılımcıların hizmet kalitesi algısı ile beklentileri arasında anlamsız ilişki bulunduğunu tespit etmiştir. Çalışmada firmanın otobüs kalkış ve varış saatlerine uymaması, otobüse biletsiz ve ayakta yolcu alması, fiyat tarifelerinin makul olmamas1, bilet fiyatlarında öğrencilere, emeklilere ve engellilere özel indirim yapılmaması gibi faktörler ön plana çıkmış ve ilgili firmaya bu yönde öneriler geliştirilmiştir. Ardıç ve Sadakoğlu (2009) tarafindan Tokat'ta şehirlerarası yolcu taşımacılığında hizmet kalitesinin ölçümüne yönelik yapılan çalışmanın sonucunda, müşteri memnuniyetine etki eden personelin tutum ve davranışları, otobüs özellikleri, dakiklik, konaklama ve mola, rezervasyon işlemleri, servis ve bagaj işlemleri ve yazıhane işlemleri olmak üzere yedi ayrı faktör belirlenmiştir. Otobüs çalışanlarının bilgisi, tecrübesi, nezaketi, güler yüzü en önemli faktör olarak belirlenirken, firma seçiminde ise en önemli faktör olarak güvenlik olduğu belirlenmiş; konfor ve fiyatın ise diğer önemli faktörler olduğu tespit edilmiştir. Çelik (2009) tarafından hizmet ortamının şehirlerarası yolcu taşıma hizmetlerinde algılanan kalite üzerindeki etkisinin incelendiği araştırmada, tüketiciler tarafından algılanan teknik ve fonksiyonel hizmet kalitesinin, şehirlerarası seyahat eden tüketicilerin davranışsal eğilimleri üzerinde etkili olduğu saptanmıştır. Şehirlerarası otobüs işletmelerinde hizmet kalitesinin belirlenmesi amacıyla Zonguldak ilinde Koçoğlu ve Aksoy (2012) tarafından gerçekleştirilen çalışmanın sonucunda, tüketicilerin hizmet kalitesi algısında otobüs işletmeleri ile ilgili nezaket, fiziki unsurlar, güvenilirlik, heveslilik ve yeterlilik faktörlerinden en yüksek düzeyde nezaket faktörü olduğu sonucuna ulaşılmıştır. Öğrencilerin hizmet kalitesi algılamalarını "yazıhane, yazıhane görevlileri ve otobüs personeline ilişkin hususlar", "otobüslere ve yolculuk esnasında sunulan hizmetlere ilişkin hususlar", "güvenilirlik ile ilgili hususlar", "şehir içi servis araçları ve görevlilerine ilişkin hususlar", "mola ile ilgili hususlar" ve "yer ayırma, bilet satın alma ve bagajlara ilişkin hususlar" şeklinde altı faktör altında inceleyen Yılmaz (2012), 
öğrencilerin söz konusu altı faktöre ilişkin hizmet kalitesi algılarının ve seyahatlere ilişkin memnuniyet düzeylerinin düşük olduğu sonucuna ulaşmıştır. Bu noktada, öğrencilerin seyahat genel memnuniyetini önemli ölçüde etkileyen faktörlerin otobüslere ve yolculuk esnasında sunulan hizmetlere ilişkin hususlar ve güvenilirlik olduğu; tekrar tercih ve tavsiye niyetleri açısından ise en önemli faktörün güvenilirlik faktörü olduğu belirlenmiştir. Memiş ve Cesur (2016) tarafından şehirlerarası yolcu taşımacıllı̆ı yapan otobüs firmalarında algılanan hizmet kalitesi ile marka bağl1lı̆̆ ilişkisinin incelendiği araştırmanın sonucuna göre, algılanan hizmet kalitesindeki olumlu değişimin marka bağl1lığı ve düzeyini de olumlu yönde etkileyerek artırdığ tespit edilmiştir. Yapraklı ve Ünalan (2016) tarafından karayolu yolcu taşımacılığında hizmet kalitesinin belirlenmesi ve hizmet kalitesinin müşteri sadakatine etkisinin araştırıldı̆̆ çalışmada, tüketicilerin hizmet kalitesi algılarının orta düzeyde olduğu belirlenmiş ve hizmet kalitesi unsurlarının müşteri sadakati üzerinde anlamlı bir etkisinin olduğu tespit edilmiştir. Aliçavuşoğlu ve Gürbüz (2017) tarafından Tokat ilinde yerel ulaşım hizmetlerinde hizmet kalite boyutlarının değerlendirildiği çalışmanın sonucunda, katılımcıların sunulan hizmetle ilgili kalite algılarının personel tutum ve davranışları, fiziksel unsurlar ve zamanında hizmet verme olmak üzere üç boyutlu bir yapıya sahip olduğu tespit edilmiştir. Özdemir ve Mısırlı (2020) tarafından, Çankırı ilinde üniversite öğrencilerinin şehirlerarası yolcu taşımacılığındaki hizmet kalitesi, davranışsal niyet ve memnuniyet ilişkisinin araştırıldığı çalışmanın sonucunda, öğrencilerin davranışsal niyetleri ile algılanan hizmet kalitesi boyutları arasında (Hizmet, servis, personel, heveslilik ve güvenlik) genel olarak anlamlı ve orta düzeyde; genel memnuniyetleri ile hizmet kalitesi boyutları arasında genel olarak anlamlı ve zayıf düzeyde ve davranışsal niyetleri ile genel memnuniyetleri arasında ise anlamlı ve orta düzeyde bir ilişki olduğu tespit edilmiştir. Literatürde yer alan bilgiler ışığında araştırmanın temel problem soruları şu şekilde geliştirilmiştir:

Araştırma sorusu 1: Şehirlerarası kara ulaşımında üniversite öğrencilerinin turizm taşıma firmalarına yönelik hizmet kalitesi algıları ne düzeydedir?

Araştırma sorusu 2: Şehirlerarası kara ulaşımında üniversite öğrencilerinin turizm taşıma firmalarına yönelik hizmet kalitesi algılarl demografik özelliklerine göre anlamlı farklllık göstermekte midir? 


\section{Yöntem}

Araştırmada veri toplama yöntemi olarak anket tekniğinden yararlanılmıştır. Afyon Kocatepe Üniversitesi öğrencileri üzerinde gerçekleştirilen anket çalışması iki bölümden oluşmaktadır. Anketin birinci bölümünde katılımcıların bazı demografik özelliklerini (cinsiyet, yaş, fakülte, ortalama aylık harcama, ailenin ortalama aylık geliri, öğrencinin konaklama şekli, seyahat nedenleri, yıllık seyahat sıklığı, firma tercihinde güven arama, daha önce aynı firma ile seyahat aralığı) belirlemeye yönelik ifadeler yer almaktadır. Araştırmanın amacına uygun olarak hazırlanmış olan anketin ikinci bölümünde ise katılımcıların hizmet kalitesi algısını belirlemek üzere 5'li Likert tipine dayanan ve daha önce farklı araştırmacılar (Duman vd., 2007; Özgüven, 2008; Ardıç ve Sadaklığlu, 2009; Yılmaz, 2012 gibi) tarafından kullanılmış olan hizmet kalitesi ölçeğinden yararlanılmıştır. Söz konusu ölçek, "yazıhane, yazıhane görevlileri ve otobüs personeline ilişkin hususlar (1-7 ifadeler)", "otobüs ve yolculuk esnasında sunulan hizmetlere ilişkin hususlar (8-11 ifadeler)", "güvenirlik ile ilgili hususlar (12-16 ifadeler)", "molaya ile ilgili hususlar (17-20 ifadeler)", "yer ayırma ve bilet satın almaya ilişkin hususlar (21-23 ifadeler)", "şehir içi servis araçları ve görevlilerine ilişkin hususlar (24-26 ifadeler)" olmak üzere toplam 6 boyut ve 26 ifadeden oluşmaktadır.

Araştırmada kullanılan ölçeğin güvenilirliğine ilişkin iç tutarlılık katsayısı olan Cronbach Alpha güvenilirlik katsayısı $\alpha$ : 0,930 olarak hesaplanmış olup, söz konusu bu değerin araştırmada kullanılması için yüksek derecede $(0,80<\alpha<1)$ güvenilir olduğu anlaşılmaktadır (Ural ve Kılıç, 2006: 286). Daha önceki araştırmalarda, söz konusu ölçeğin faktör yapısının belirlenmesi amacıyla temel bileşenler analizi ve Varimax rotasyonu kullanılarak faktör analizi yapıldığı için tekrar faktör analizi yapılmasına gerek duyulmamıştır.

Araştırmanın evrenini Afyon Kocatepe Üniversite'sinde eğitim alan öğrenciler oluşturmaktadır. $\mathrm{Bu}$ doğrultuda tamsayım imkanının güç olması, araştırmacıların imkanları ve ulaşım olanakları göz önünde bulundurularak, 2019/2020 Eğitim-Öğretim yılı akademik takvime göre vize sınavlarının bitiş tarihi olan 15 Kasım 2019 ile 29 Kasım 2019 tarihleri arasında tesadüfi olarak otogarda bulunan öğrenciler üzerinde anket tekniği uygulanmış olup, toplamda 800 anket dağıtılmıştır. Geri dönen anketlerden 77 tanesinin eksik veya hatalı doldurulması gibi nedenlerden dolayı elenmesiyle birlikte, toplamda 723 kullanılabilir anket araştırmaya dahil edilmiştir.

Elde edilen verilerin istatistiki analizi için; katılımcıların demografik özelliklerine yönelik frekans ve yüzde dağılımları, değişkenler arasındaki farklılaşma için Anova ve t testi ve boyutlar arasındaki ilişki için ise korelasyon analizlerinden yararlanılmıştır. Analiz sonucunda elde edilen bulgular araştırmanın amacına uygun olarak yorumlanmıştır. 


\section{Bulgular}

Araştırma kapsamında incelenen 723 üniversite öğrencisinin bazı bireysel özelliklerini belirlemeye yönelik frekans ve yüzde dağılımları Tablo 1'de ayrıntılı olarak sunulmuştur. Tablo 1 incelendiğinde, katılımcıların \%52,8'ini kadınlar, \%47,2'sini ise erkekler oluşturmaktadır. Katılımcıların yaş değişkenleri göz önüne alındığında, \%56,4'ü 21-23 yaş arasında iken, \%25,7'si ise 20 yaş ve altındadır. Katılımcıların \%33,3'ünün barınma harcamalarının dışında ortalama aylık harcaması $201 \mathrm{TL}$ ile $400 \mathrm{TL}$ arasındayken, \%36,7'sinin harcaması ise $401 \mathrm{TL}$ ile $600 \mathrm{TL}$ arasındadır. Öğrencilerin \%29,3'ünün ailesinin ortalama aylık geliri 1500 TL ve altında, \%26,8'inin 1501 TL ile 2000 TL arasında, \%18,4'ünün 2001 TL ile 2500 TL arasında ve \%25,4'ünün ise $2500 \mathrm{TL}$ ve üzerinde olduğu görülmektedir. Genel itibariyle incelendiğinde, araştırmanın örneklem grubundan yola çıkarak karayolu ulaşımında otobüs işletmelerini seçen öğrenci kitlesinin aile maddi durumunun ortanın oldukça altında olduğu söylenebilir.

Tablo 1: Katılımcıların Bireysel Özelliklerine İlişkin Bulgular

\begin{tabular}{|c|c|c|c|c|c|c|c|}
\hline Değişkenler & Gruplar & $\mathbf{f}$ & $\%$ & Değişkenler & Gruplar & $\mathbf{f}$ & $\%$ \\
\hline \multirow{2}{*}{ Cinsiyeti } & Kadın & 382 & 52,8 & \multirow{13}{*}{$\begin{array}{c}\text { Eğitim } \\
\text { aldığ1 } \\
\text { Fakülte / } \\
\text { Yüksekokul }\end{array}$} & Ĕgitim & 80 & 11,1 \\
\hline & Erkek & 341 & 47,2 & & Fen-Edebiyat & 146 & 20,2 \\
\hline \multirow{4}{*}{ Yaş1 } & 20 yaş ve altı & 186 & 25,7 & & İ.İ.B.F. & 208 & 28,8 \\
\hline & 21-23 yaş arası & 408 & 56,4 & & Tip & 12 & 1,7 \\
\hline & 24-26 yaş arası & 107 & 14,8 & & Turizm & 112 & 15,5 \\
\hline & 27 yaş ve üstü & 22 & 3,0 & & Mühendislik & 46 & 6,4 \\
\hline \multirow{4}{*}{$\begin{array}{c}\text { Ortalama } \\
\text { Aylık } \\
\text { Harcama (Ev- } \\
\text { yurt hariç) }\end{array}$} & 200 TL ve alt1 & 58 & 8,0 & & Veterinerlik & 13 & 1,8 \\
\hline & 201-400 TL aras1 & 241 & 33,3 & & Güzel Sanatlar & 16 & 2,2 \\
\hline & 401-600 TL aras1 & 265 & 36,7 & & Teknoloji & 30 & 4,1 \\
\hline & 601 TL ve üstü & 159 & 22,0 & & İlahiyat & 2 & 0,3 \\
\hline \multirow{4}{*}{$\begin{array}{c}\text { Ailenin } \\
\text { Ortalama } \\
\text { Aylık Geliri }\end{array}$} & 1500 TL ve alt1 & 212 & 29,3 & & Hukuk & 11 & 1,5 \\
\hline & $1501-2000 \mathrm{TL}$ aras1 & 194 & 26,8 & & M.Y.O. & 31 & 4,3 \\
\hline & 2001-2500 TL aras1 & 133 & 18,4 & & Diğer & 16 & 2,2 \\
\hline & 2500 TL ve üzeri & 184 & 25,4 & \multirow{6}{*}{$\begin{array}{c}\text { Y1llık } \\
\text { Seyahat } \\
\text { Siklığ1 }\end{array}$} & Haftada 1 Defa & 23 & 3,2 \\
\hline \multirow{6}{*}{$\begin{array}{c}\text { Öğrencinin } \\
\text { Konaklama } \\
\text { Şekli }\end{array}$} & KYK Yurdu & 334 & 46,2 & & Haftada 2-3 Defa & 18 & 2,5 \\
\hline & Özel Yurt & 164 & 22,7 & & Ayda 1 Defa & 227 & 31,4 \\
\hline & Evde Tek Başına & 31 & 4,3 & & Ayda 2-3 Defa & 155 & 21,4 \\
\hline & Evde Arkadaşıla & 129 & 17,8 & & Yilda Birkaç Defa & 246 & 34,0 \\
\hline & Evde Ailesiyle & 61 & 8,4 & & Diğer & 54 & 7,5 \\
\hline & Diğer & 4 & 0,6 & \multirow{6}{*}{$\begin{array}{l}\text { Seyahat } \\
\text { Etme } \\
\text { Nedeni }\end{array}$} & Aile Ziyareti & 299 & 41,4 \\
\hline \multirow{5}{*}{$\begin{array}{c}\text { Firmada } \\
\text { Güven Arama } \\
\text { Aynı Firma ile } \\
\text { Seyahat } \\
\text { Aralığ } 1\end{array}$} & Evet & 538 & 74,4 & & Ĕgitim & 56 & 7,7 \\
\hline & Hayır & 185 & 25,6 & & Tatil & 66 & 9,1 \\
\hline & 2 Defa ve Alt1 & 30 & 4,1 & & Gezmek & 105 & 14,5 \\
\hline & 3-4 Defa & 108 & 14,9 & & Memleket Ziyareti & 84 & 11,6 \\
\hline & 5 Defa ve Fazlası & 585 & 80,9 & & Diğer & 113 & 15,6 \\
\hline Toplam & & 723 & 100 & & & 723 & 100 \\
\hline
\end{tabular}

Araştırmaya katılan öğrencilerin \%46,2'si Kredi ve Yurtlar Genel Müdürlügü̈’ne bağl1 devlet yurtlarında, \%22,7'si özel öğrenci yurtlarında ve \%31,1’i ise evde ya da ailesinin yanında 
konaklamaktadır. Yurtlarda kalan öğrencilerin oranı $(\% 68,9)$ incelendiğinde, yine kendilerinin ve ailelerinin ekonomik gücü ile ilgili olabileceği yorumu yapılabilir. Araştırmaya katılan öğrencilerin eğitim gördükleri fakülte / yüksekokul incelendiğinde, en fazla katılımın \%28,8 ile İktisadi ve İdari Bilimler Fakültesi, \%20,2 ile Fen-Edebiyat Fakültesi ve \%15,5 ile Turizm Fakültesi tarafindan gerçekleştirilmiş olduğu görülmektedir.

Öğrencilerin seyahat sıklığı incelendiğinde, \%34,0 ile yılda birkaç defa, \%31,4 ile ayda bir defa ve \%21,4 ile ayda 2-3 defa şeklinde yanıt verdikleri anlaşılmaktadır. Katılımcıların en fazla seyahat etme nedenini belirlemek üzere yöneltilen ifadeye öğrencilerin büyük bir bölümünü oluşturan \%41,4'ü aile ziyareti amaciyla, \%14,5'i gezmek amaciyla ve \%11,6's1 ise memleket ziyareti amacıyla seyahat ettiği yönünde görüş bildirmiştir. Seyahat için firmaların güvenirliğini araştırıp araştırmadıklarını belirlemek üzere yöneltilen ifadeye ise öğrencilerin \%74,4'ü "evet" yanıtını vererek, firma tercihlerinde güvenliğin çok önemli olduğu yönünde görüş bildirirken, \%25,6'sı "hayır" yanıtını vermiştir. Araştırmaya katıldıkları esnada tercih ettikleri otobüs firmasıyla daha önce kaç defa daha seyahat ettiklerini belirlemek amacıyla yöneltilen ifadeye katılımcıların neredeyse tamamına yakını $(\% 80,9)$, aynı firma ile daha önce 5 ve daha fazla seyahat ettiğini, \%14,9'u 3-4 defa ve \%4,1'i ise 2 defa ya da daha az seyahat ettiğini bildirmiştir.

Tablo 2'de karayolu ulaşımındaki otobüs işletmelerinin hizmet kalitesine yönelik "yazlhane, yazlhane görevlileri ve otobüs personeli", "otobüs ve yolculuk esnasinda sunulan hizmetler", "güvenirlik", "mola", "yer ayırma ve bilet satın alma", "şehir içi servis araçları ve görevlileri" olmak üzere altı alt boyuta ait ve genel hizmet kalitesine ait aritmetik ortalama ve standart sapma değerleri verilmiştir.

Tablo 2: Hizmet Kalitesi ve Alt Boyutlarına İlişkin Aritmetik Ortalama ve Standart Sapma Değerleri

\begin{tabular}{lcc}
\hline \multicolumn{1}{c}{ Hizmet Kalitesi Boyutları } & $\overline{\mathbf{x}}$ & s.s. \\
\hline Yazıhane, Yazıhane Görevlileri ve Otobüs Personeli & 3,34 & 1,08 \\
\hline Otobüs ve Yolculuk Esnasında Sunulan Hizmetler & 3,17 & 1,30 \\
\hline Güvenirlik & 3,19 & 1,09 \\
\hline Mola & 3,49 & 1,36 \\
\hline Yer Ayırma ve Bilet Satın Alma & 3,54 & 1,39 \\
\hline Şehir İçi Servis Araçları ve Görevlileri & 2,90 & 1,10 \\
\hline Genel & $\mathbf{3 , 2 8}$ & $\mathbf{1 , 2 4}$ \\
\hline
\end{tabular}

Araştırma problemi kapsamında araştırmada yanıt aranan araştırma sorularından ilki olan "şehirlerarası kara ulaşımında üniversite öğrencilerinin turizm taşıma firmalarına yönelik hizmet kalitesi algıları ne düzeydedir?" sorusunun yanıtı Tablo 2'de ayrıntılı olarak gösterilmektedir. Tablo 2'deki değerlere göre, şehirlerarası kara ulaşımında üniversite öğrencilerinin turizm taşıma firmalarına yönelik genel hizmet kalitesi algıları $(\bar{x}=3,28)$ orta düzeyin biraz üste bulunmuştur. Boyutlar açısından ele alındığında ise, en yüksekten en düşük aritmetik ortalamaya sahip olmasına göre, en yüksek $\bar{x}=3,54$ aritmetik ortalama ile yer ayırma ve bilet satın alma boyutundaki hizmet kalitesi algıs1; $\overline{\mathrm{x}}=3,49$ ile mola boyutundaki hizmet kalitesi algıs1; $\overline{\mathrm{x}}=3,34$ ile 
yazıhane, yazıhane görevlileri ve otobüs personeli boyutundaki hizmet kalitesi algisı; $\bar{x}=3,19$ ile güvenirlik boyutundaki hizmet kalitesi algıs1; $\bar{x}=3,17$ ile otobüs ve yolculuk esnasında sunulan hizmetler boyutundaki hizmet kalitesi algısı ve en düşük $\bar{x}=2,90$ aritmetik ortalama ile şehir içi servis araçları ve görevlileri boyutundaki hizmet kalitesi algısı takip etmektedir. Dolayısıyla katılımcıların verdikleri yanıtlar açısından, otobüs firmalarının sunduğu "rezervasyon ve bilet satın alma işlemleri" tüketicilerin hizmet kalitesi algısını artırırken, "şehir içi servis araçları ve görevlileri” ise bu algıyı azalttığı yorumu yapılabilir.

Araştırma kapsamında yanıt aranan diğer bir araştırma sorusu olan "şehirlerarası kara ulaşımında üniversite ögrencilerinin turizm taşıma firmalarına yönelik hizmet kalitesi algıları demografik özelliklerine göre anlaml farklllık göstermekte midir?" sorusunun yanıtı için; katılımcıların demografik özellikleri ile hizmet kalitesi algıları arasında anlamlı farklılıklar olup olmadığını test etmek amacıyla bağımsız iki grup için $t$ testi, ikiden fazla gruplar için ise tek yönlü varyans (One Way Anova) analizinden yararlanılmıştır. Bu noktada, yapılan testlerin sonuçlarına göre katılımcıların hizmet kalitesi algıları sadece güvenirlik boyutunda aylık harcama düzeylerine $(p<0,05)$ göre değişmekte olup, diğer hiçbir bireysel özelliğe göre anlamlı bir farklılık $(p>0,05)$ tespit edilmemiştir. Katılımcıların hizmet kalitesi boyutunda güvenirlik puanları karşılaştıııldığında, katılımcıların ortalama aylık harcama miktarlarına göre istatistiki açıdan anlamlı bir farklılık $(\mathrm{F}=3,382 ; \mathrm{p}=0,018<0,05)$ olduğu belirlenmiştir. Farklılığın kaynağını belirlemek üzere yapılan Çoklu Karşılaştırma Tukey testinin sonucunda ortalama değerleri incelendiğinde, ortalama aylık harcama düzeyi 401 TL ile 600 TL arasında olan katılımcıların $(\bar{x}=3,29 \pm 1,33)$ otobüs firmalarına yönelik hizmet kalitesi algılarında güvenirlik düzeyi diğer gruplara oranla daha yüksek bulunmuştur.

Araştırmaya dahil edilen 723 üniversite öğrencisinin karayolu ulaşımında otobüs firmalarına yönelik hizmet kalitesi algılarının incelendiği bu araştırmada, hizmet kalitesine ait alt boyutlar arasındaki ilişkinin belirlenmesi amacıyla korelasyon analizinden yararlanılmıştır. Ural ve Kılıç (2006) tarafından da belirtildiği üzere, değişkenler arasındaki ilişkilerin derecesini, şiddetini ve gücünü belirlemek amacıyla korelasyon analizinden yararlanılmaktadır. Değişkenler arasındaki ilişkinin düzeyini ifade eden korelasyon katsayısının $\left(\mathrm{r}^{2}\right)$ 0-0,29 arasında bulunması halinde zayıf; 0,30-0,64 arasinda bulunması halinde orta; 0,65-0,84 arasinda bulunması halinde yüksek ve 0,85-1 arasında bulunması halinde ise çok yüksek olduğu ifade edilmektedir. Hizmet kalitesinin alt boyutları arasındaki ilişkinin belirlenmesi amacıyla gerçekleştirilen korelasyon analizinin sonuçları Tablo 3'te ayrıntılı olarak gösterilmektedir. 
Tablo 3: Katılımcıların Hizmet Kalitesi ve Alt Boyutları Arasındaki İlişkiye Ait Korelasyon Matrisi

\begin{tabular}{|c|c|c|}
\hline Değişkenler (Alt Boyutlar) & $\begin{array}{c}\text { Korelasyon Katsayısı / } \\
\text { Anlamlılık / Belirlilik Katsayısı }\end{array}$ & $\begin{array}{l}\text { Hizmet Kalitesi Algısı } \\
(\text { Genel } \bar{x}=\mathbf{3}, 28)\end{array}$ \\
\hline \multirow{3}{*}{$\begin{array}{c}\text { Yazıhane, Yazıhane Görevlileri ve } \\
\text { Otobüs Personeli }(\overline{\mathrm{x}}=3,34)\end{array}$} & $\mathrm{r}$ & $0,518^{* *}$ \\
\hline & $\mathrm{p}$ & $0,000^{* * *}$ \\
\hline & $\mathrm{r}^{2}$ & 0,268 \\
\hline \multirow{3}{*}{$\begin{array}{l}\text { Otobüs ve Yolculuk Esnasinda } \\
\text { Sunulan Hizmetler }(\overline{\mathrm{X}}=3,17)\end{array}$} & $\mathrm{r}$ & $0,713^{* *}$ \\
\hline & $\mathrm{p}$ & $0,000^{* * *}$ \\
\hline & $\mathrm{r}^{2}$ & 0,508 \\
\hline \multirow{3}{*}{ Güvenirlik $(\overline{\mathrm{x}}=3,19)$} & $\mathrm{r}$ & $0,500^{* *}$ \\
\hline & $\mathrm{p}$ & $0,000^{* * *}$ \\
\hline & $\mathrm{r}^{2}$ & 0,250 \\
\hline \multirow{3}{*}{ Mola $(\bar{x}=3,49)$} & $\mathrm{r}$ & $0,836^{* *}$ \\
\hline & $\mathrm{p}$ & $0,000^{* * *}$ \\
\hline & $\mathrm{r}^{2}$ & 0,699 \\
\hline \multirow{3}{*}{$\begin{array}{l}\text { Yer Ayırma ve Bilet Satın Alma } \\
\qquad(\bar{x}=3,54)\end{array}$} & $r$ & $0,408^{* *}$ \\
\hline & $\mathrm{p}$ & $0,000^{* * *}$ \\
\hline & $\mathrm{r}^{2}$ & 0,167 \\
\hline \multirow{3}{*}{$\begin{array}{c}\text { Şehir İçi Servis Araçları ve } \\
\text { Görevlileri }(\overline{\mathrm{x}}=2,90)\end{array}$} & $\mathrm{r}$ & $0,442^{* *}$ \\
\hline & $\mathrm{P}$ & $0,000^{* * *}$ \\
\hline & $\mathrm{r}^{2}$ & 0,195 \\
\hline
\end{tabular}

Tablo 3'te görüldüğü gibi, katılımcıların kara ulaşımında otobüs firmalarına yönelik hizmet kalitesi algıları ve alt boyutları arasındaki ilişki 0,01 anlamlılık düzeyinde anlamlı bulunmuştur $(\mathrm{p}=0,000<0,01)$. Tablo 3 'te görüldüğü gibi, katılımcıların kara ulaşımında otobüs firmalarına yönelik hizmet kalitesi algıları ve alt boyutları arasındaki ilişki 0,01 anlamlılık düzeyinde anlamlı bulunmuştur $(\mathrm{p}=0,000<0,01)$. Katılımcıların yazıhane, yazıhane görevlileri ve otobüs personeli boyutundaki hizmet kalitesi algıları ile genel hizmet kalitesi algıları arasında pozitif yönlü ve orta düzeyde bir ilişki olduğu tespit edilmiştir $(r=0,518)$. Belirlilik katsayısı olan $\mathrm{r}^{2}$ değeri incelendiğinde, katılımcıların genel hizmet kalitesi algılarındaki toplam varyansın $\% 26,8$ 'inin yazıhane, yazıhane görevlileri ve otobüs personeli boyutundan kaynaklandığı anlaşılmaktadır $\left(\mathrm{r}^{2}=0,268\right)$. Otobüs ve yolculuk esnasında sunulan hizmetler boyutundaki hizmet kalitesi algıları ile genel hizmet kalitesi algıları arasında pozitif yönlü ve yüksek düzeyde bir ilişki $(\mathrm{r}=0,713)$ olup, belirlilik katsayısına göre katılımcıların genel hizmet kalitesi algılarındaki toplam varyansın \%50,8'inin otobüs ve yolculuk esnasında sunulan hizmetler boyutundan kaynaklandığ 1 anlaşılmaktadır $\left(r^{2}=0,508\right)$. Güvenirlik boyutundaki algıları ile genel algıları arasında pozitif yönlü ve orta düzeyde bir ilişki $(r=0,500)$ olduğu belirlenmiştir. Güvenirlik boyutunun belirlilik katsayısı dikkate alındığında, katılımcıların genel hizmet kalitesi algılarındaki toplam varyansın $\% 25$ 'inin güvenirlik boyutundan kaynaklandığ 1 görülmektedir $\left(r^{2}=0,250\right)$. Kat1lımcıların en yüksek düzeyde hesaplanmış olan mola boyutundaki hizmet kalitesi algıları ile genel algıları arasında pozitif yönlü ve oldukça yüksek düzeyde bir ilişki $(r=0,836)$ olduğu tespit edilmiştir. Mola boyutunun belirlilik katsayısına göre, katılımcıların genel hizmet kalitesi algılarındaki toplam varyansın \%69,9'unun mola boyutundan kaynaklanmaktadır $\left(\mathrm{r}^{2}=0,699\right)$. Katılımcıların yer 
ayırma ve bilet satın alma boyutundaki hizmet kalitesi alg1ları ile genel algıları arasında pozitif yönlü ve orta düzeyde bir ilişki $(r=0,408)$ olduğu görülmektedir. Yer ayırma ve bilet satın alma işlemlerini kapsayan alt boyut, katılımcıların genel hizmet kalitesi algılarındaki toplam varyansın $\% 16,7$ 'sini oluşturmaktadır $\left(\mathrm{r}^{2}=0,167\right)$. Tablo 3 'teki değerlere göre, söz konusu boyutun aritmetik ortalamasının yüksek olmasına rağmen, genel hizmet kalitesi algısının toplam varyansı üzerinde çok etkili olmadığı tespit edilmiştir. Katılımcıların şehir içi servis araçları ve görevlileri boyutundaki hizmet kalitesi algıları ile genel hizmet kalitesi algıları arasında da pozitif yönlü ve orta düzeyde bir ilişki olduğu olduğu belirlenmiştir $(r=0,442)$. İlgili boyutun belirlilik katysayısı incelendiğinde, katılımcıların genel hizmet kalitesi algılarındaki toplam varyansın \%19,5'inin şehir içi servis araçları ve görevlileri boyutundan kaynaklandığı sonucuna ulaşılmıştır $\left(\mathrm{r}^{2}=0,195\right)$.

\section{Sonuç, Tartışma ve Öneriler}

$\mathrm{Bu}$ araştırmada, karayolu ulaşımında otobüs işletmelerini sıklıkla kullanan üniversite öğrencilerinin hizmet kalitesi algılarını belirlemek amaçlanmıştır. Otobüs işletmelerinin sunduğu hizmetler "yazıhane, yazıhane görevlileri ve otobüs personeli", "otobüs ve yolculuk esnasında sunulan hizmetler", "güvenirlik", "mola", "yer ayırma ve bilet satın alma işlemleri" ve "şehir içi servis araçları ve görevlileri" olmak üzere toplam altı boyut üzerinden değerlendirilmiştir. Genel olarak katılımcıların otobüs firmalarına yönelik hizmet kalitesi algıları orta düzeyin biraz üzerinde $(\overline{\mathrm{x}}=3,28$; s.s.: 1,24$)$ bulunmuştur. Hizmetleri kullanan üniversite öğrencilerinin hizmet kalitesi algısında en yüksek puana sahip olan faktörden en düşük puana sahip olan faktöre doğru sırasıyla "yer ayırma ve bilet satın alma işlemleri ( $\bar{x}=3,54$; s.s.: 1,39$)$ "; "mola $(\bar{x}=3,49$; s.s.: 1,36)"; "yazıhane, yazıhane görevlileri ve otobüs personeli ( $\bar{x}=3,34$; s.s. 1,08)"; "güvenirlik ( $\bar{x}=3,19$; s.s.: $1,09)$; "otobüs ve yolculuk esnasında sunulan hizmetler $(\bar{x}=3,17$; s.s.: 1,30$)$ ve "şehir içi servis araçları ve görevlileri $(\overline{\mathrm{x}}=2,90$; s.s.: 1,10$)$ " faktörleri olduğu tespit edilmiştir.

Araştırma verilerinin analizinden elde edilen bulgular doğrultusunda, otobüs firmalarının sunduğu "rezervasyon ve bilet satın alma işlemleri” tüketicilerin hizmet kalitesi algısını artırırken, "şehir içi servis araçları ve görevlileri” ise bu algıyı azalttığını söylemek mümkündür. Araştırmadan elde edilen söz konusu bu sonuçların, daha önce konuyla ilgili Türkiye'de yapılmış olan çoğu akademik çalışmanın (Tan ve Bektaş, 2002; Çatı, 2003; Duman vd., 2007; Alnıç̧ı ve Özbek, 2009; Ardıç ve Sadakoğlu, 2009; Yılmaz, 2012; Memiş ve Cesur, 2016; Aliçavuşoğlu ve Gürbüz, 2017; Özdemir ve Mısırlı, 2020 gibi) sonuçlarıyla benzerlik ve paralellik gösterdiği tespit edilmiştir. Örneğin, Tan ve Bektaş (2002) tarafından yapılan araştırmanın sonucunda, ikramlardaki yetersizlik, yetersiz şehir içi servisleri, durak dışı yolcu alma-indirme gibi faktörler tüketicilerin hizmet kalitesi algılarını olumsuz yönde etkilediği belirtilmektedir. Çatı (2003) 
tarafından yapılan çalışmada, araçlara fazla yolcu alınması ve personel davranışlarının olumsuzlukları tüketicilerin hizmet kalitesi algısını olumsuz yönde etkilediği sonucuna ulaşılmıştır. Duman vd. (2007) tarafından yapılan çalışmada, yazıhane-servis-terminal hizmetleri, seyahat süresinde alınan hizmetler ve mola yeri hizmetlerinin tüketici hizmet kalitesi algılarını etkilediği tespit edilmiştir. Alnıaçık ve Özbek (2009) yaptıkları çalışmanın sonucunda, bir otobüs firmasına yönelik üniversite öğrencilerinin hizmet kalitesi algısı ile beklentileri (zamanında hareket ve varış, durak harici yolcu indirme-bindirme, yüksek fiyatlar vb.) arasında anlamsız bir ilişki olduğu belirtilmiştir. Ardıç ve Sadakoğlu (2009) da müşteri memnuniyetine etki eden faktörlerin personelin tutum ve davranışları, otobüs özellikleri, zamanındalık, konaklama ve mola, rezervasyon işlemleri, servis ve bagaj işlemleri ve yazıhane işlemleri faktörlerinden oluştuğunu belirtmiştir. Bu çalışmada da kullanılan faktörler altında hizmet kalitesi algısını inceleyen Yılmaz (2012) yaptığı araştırmada, öğrencilerin otobüs firmalarına yönelik hizmet kalitesi algılarının ve seyahatlere ilişkin memnuniyet düzeylerinin düşük olduğu sonucuna ulaşmıştır. Öğrencilerin seyahat genel memnuniyetini önemli ölçüde etkileyen faktörlerin otobüslere ve yolculuk esnasında sunulan hizmetlere ilişkin hususlar ve güvenilirlik olduğunu, ayrıca tekrar tercih ve tavsiye niyetleri açısından ise en önemli faktörün güvenilirlik faktörü olduğu tespit edilmiştir. Memiş ve Cesur (2016) tarafından şehirlerarası yolcu taşımacılığı yapan otobüs firmalarında algılanan hizmet kalitesi ile marka bağl11 $\breve{g ̆}_{1}$ ilişkisinin incelendiği araştırmada iki değişken arasında anlamlı ilişkiler olduğu sonucuna ulaşılmıştır. Aliçavuşoğlu ve Gürbüz (2017), çalışmalarında katılımcıların otobüs işletmeleri tarafından sunulan hizmetle ilgili kalite algıları üzerinde personel tutum ve davranışları, fiziksel unsurlar ve zamanında hizmet verme faktörlerinin etkili olduğu sonucuna ulaşmıştır. Özdemir ve Mısırlı (2020) da yaptıkları çalışma sonucunda, şehirlerarası otobüs işletmeleri ile ilgili öğrencilerin davranışsal niyetleri ile algılanan hizmet kalitesi boyutları arasında (Hizmet, servis, personel, heveslilik ve güvenlik) genel olarak anlamlı ve orta düzeyde bir ilişki olduğunu belirtmiştir. Yapılan bu çalışmaların kronolojik sırayla incelenmesindeki sebep ise geçmiş yıllardan bugüne farklılık olup olmadığını test etmektir. Ancak, genel olarak ele alındığında tüketicilerin hizmet kalitesi algılarının hemen aynı faktörlerden etkilendiği görülmektedir.

Araştırmaya katılan üniversite öğrencilerinin demografik özelliklerine göre hizmet kalitesi algıları arasında anlamlı bir farklılık olup olmadığı test edilmiştir. Yapılan t-testi ve varyans analizi sonuçlarına göre, katılımcıların hizmet kalitesi algıları sadece güvenirlik boyutunda aylık harcama düzeylerine $(\mathrm{p}<0,05)$ göre değişmekte olup, diğer hiçbir bireysel özelliğe göre anlamlı bir farklılık $(\mathrm{p}>0,05)$ tespit edilmemiştir. Katılımcıların hizmet kalitesi boyutunda güvenirlik puanları karşılaştırıldığında, katılımcıların ortalama aylık harcama miktarları 401 TL ile 600 TL arasında olan katılımcıların $(\overline{\mathrm{x}}=3,29 \pm 1,33)$ otobüs firmalarına yönelik hizmet kalitesi algılarında güvenirlik düzeyi diğer gruplara oranla daha yüksek bulunmuş 
ve değişkenler arasında istatistiki olarak anlamlı bir farkl11ık $(\mathrm{F}=3,382 ; \mathrm{p}=0,018<0,05)$ olduğu sonucuna ulaşılmıştır. Yapılan korelasyon analizinin sonucunda ise öğrencilerin genel hizmet kalitesi algısı ile alt boyutları arasında genel itibariyle pozitif yönlü ve orta düzeyde ilişkiler olduğu saptanmıştır. Yapılan bu araştırmadan elde edilen ve daha önce yapılmış diğer akademik çalışmaların sonuçlarından yola çıkarak ilgili işletmeler ve ileride yapılacak diğer akademik çalışmalar için bazı öneriler sunmakta yarar olduğu düşünülmektedir;

Özellikle, otobüs firmalarının daha iyi hizmet verebilmesi adına yolculuk, otobüs ve çalışanlarının yanı sıra şehir içi servis araçlarını, saatlerini ve çalışanları üzerinde de önemle durulmalı ve iyileştirme çalışmaları yapılmalıdır. Önemli faktörlerden bir diğeri zamanında kalkış ve varış ile duraklar haricinde yolcu alma ya da indirmedir. Bununla ilgili yasakların yürürlüğe girmiş olmasına rağmen, bazı işletmelerin bu duruma uyum göstermediği bilinmektedir. Hem tüketicilerin mağdur edilmemesi hem de işletmenin itibarı, güvenirliği ve sürdürülebilir verimliliği için zamanında kalkış ve zamanında varış ilkeleri benimsenmelidir. Daha önce de belirtildiği üzere, özellikle eğitim-öğretim dönemlerinde otobüs işletmelerinin toplam yolcu kapasitelerinin büyük bir bölümü öğrenciler tarafından oluşmaktadır. Bu noktada, işletmeler öğrenci indirimleri, tekrar tercih edilmesi durumunda farklı tarifeler uygulanması, puan sistemleri gibi kampanyalar yürütebilir. Çünkü hizmet kalitesi, tüketici memnuniyeti, bağlılığı, sadakati, tekrar tercih etmesi, tavsiye etmesi ve böylelikle işletmelerin verimliliği ve rekabet avantajı elde etmesi üstünde oldukça etkilidir. Bu çalışma ve buna benzeyen birçok çalışma memnuniyet, hizmet kalitesi algısı gibi konular dahilinde tüketici gruplanı üzerinde yapılmıştır. İleride yapılacak olan çalışmalar da hizmeti sunan taraf olan işletmeciler ve işletme çalışanlarının memnuniyetleri, sorunları ya da davranışları üzerinde yapılabilir. Böylelikle, hem hizmeti satın alan tüketici gruplarının hem de hizmeti sağlayan üretici gruplarının memnuniyet düzeyleri belirlenebilir, çözüme kavuşturmaya yönelik sorunları ortaya konulabilir.

Yazar Katkıları: Çalışma için gerekli olan verilerin toplanması, analizi ve raporlanması ile birlikte çalışmada yer alan giriş, literatür, yöntem, sonuç ve tartışma bölümlerinin yazılmasında her iki yazarın da katkıları eşit orandadır.

Çıkar Beyanı: Yazarlar arasında herhangi bir çatışması bulunmamaktadır.

\section{Kaynakça}

Aliçavuşoğlu, Ç. ve Gürbüz, A. (2017). Yerel Ulaşım Hizmetlerinde Hizmet Kalite Boyutlarının Değerlendirilmesi. PESA Uluslararası Sosyal Araştırmalar Dergisi, 3(4), 74-86.

Alnıaçık Ü. ve Özbek V. (2009). Otobüs İşletmelerinde hizmet Kalitesinin Ölçümü-Kandıra Gürkan Turizm Örneği. Uluslararası Íktisadi ve İdari İncelemeler Dergisi, 1(3), 125137. 
Ardıç K. ve Sadaklığlu H. (2009). Şehirlerarası Yolcu Taşımacılığında Hizmet Kalitesinin Ölçümü: Tokat Örneği. Atatürk Üniversitesi İktisadi ve İdari Bilimler Dergisi, 23(3).167190.

Başanbaş, Ş. (2013). Algılanan Kalite ile Müşteri Tatmini Arasındaki İlişki: Filtre Kullanıcıları Üzerine Yapılan Ampirik Bir Çalışma. Akademik Bakış Dergisi, 34(1), 1-21.

Çat1, K. (2003). Ulaşım Hizmetlerinde Hizmet Kalitesi ve Bir Uygulama. Cumhuriyet Üniversitesi Sosyal Bilimler Dergisi, 27(1), 121-134.

Çatı K. ve Yıldız S. (2005). Şehirlerarası otobüs İşletmelerinde Hizmet Kalitesinin Ölçülmesi ve Bir Uygulama. Hacettepe Üniversitesi İktisadi ve İdari Bilimler Fakültesi Dergisi, 23(2), 121-144.

Çelik H. (2009). Hizmet Ortamının Şehirlerarası Yolcu Taşıma Hizmetlerinde Algılanan Kalite Üzerindeki Etkisinin İncelenmesi. İstanbul Üniversitesi Işsletme Fakültesi Dergisi, 38(2), 157-183.

Çiçek, R. ve Doğan, İ. C. (2009). Müşteri Memnuniyetinin Artırılmasında Hizmet Kalitesinin Ölçülmesine Yönelik Bir Araştırma: Niğde İli Örneği. Afyon Kocatepe Üniversitesi İ.I.B.F. Dergisi, 11(1), 199-217.

Duman T., Ayduğan P. ve Koçak G. N. (2007). Karayolu Yolcu Taşımacıllğı Hizmetlerinde Hizmet Kalitesi, Hizmet Değeri, Müşteri Memnuniyeti ve Müşteri Sadakati İlişkileri. Dokuz Eylül Üniversitesi Sosyal Bilimler Enstitüsü Dergisi, 9(1), 151-177.

Gržinić, J. (2007). Concepts of Service Quality Measurement in Hotel Industry. Ekon. Misao Praksa Dbk. God., 16(1), 81-98.

Güçer, E., Silik, C. E. ve Demirdağ, Ş. A. (2017). Turistlerin Animasyon Hizmetlerine Yönelik Kalite Algılamalarının Belirlenmesi: Beş Yıldızlı Oteller Üzerine Bir Çalışma. İçinde: Bilici, N., Pehlivanl1, R. ve Ashirkhanova, Karlygash (eds.), Innovation and Global Issues in Social Sciences Congress Book. April 27-29, 2017, Antalya. Antalya, Inglobe Platform, 454-473.

Hernon, P. ve Nitecki, D. A. (2001). Service Quality: A Concept Not Fully Explored. Library Trends, 49(4), 687-708.

Iacobucci, D., Ostrom, A. ve Grayson, K. (1995). Distinguishing Service Quality and Customer Satisfaction: The Voice of the Consumer. Journal of Consumer Psychology, 4(3), 277303.

Kâmil Koç, (2020), Türkiye'de Şehirlerarası Otobüs Yolculuğunun Tarihçesi. https://blog.kamilkoc.com.tr/arsivler/5145, (Erişim Tarihi: 05.06.2020).

Koçoğlu, C. M. ve Aksoy, R. (2012). Hizmet Kalitesinin SERVPERF Yöntemi ile Ölçülmesi: Otobüs İşletmeleri Üzerinde Bir Uygulama. Akademik Bakış Dergisi, 29(2012), 1-20.

Memiş, S. ve Cesur, Z. (2016). Algılanan Hizmet Kalitesi ile Marka Bağlılı̆̆ı İlişkisi Şehirlerarası Yolcu Taşımacılığı Yapan Otobüs Firmaları Üzerine Bir Araştırma. Celal Bayar Üniversitesi Sosyal Bilimler Dergisi, 14(2), 453-484.

Okumuş, A. ve Duygun, A. (2008). Eğitim Hizmetlerinin Pazarlanmasında Hizmet Kalitesinin Ölçümü ve Algılanan Hizmet Kalitesi ile Öğrenci Memnuniyeti Arasındaki İlişki. Anadolu Üniversitesi Sosyal Bilimler Dergisi, 8(2), 17-38.

Özdemir, H. ve Mısırlı İ. (2020). Şehirlerarası Yolcu Taşımacılığında Hizmet Kalitesi, Davranışsal Niyet ve Memnuniyet İlişkisi: Çankırı Karatekin Üniversitesi Örneği. Turkish Studies - Social Sciences, 15(2), 281-299.

Özgüven N. (2008). Hizmet Pazarlamasında Müşteri Memnuniyeti ve Ulaştırma Sektörü Üzerine Bir Uygulama. Ege Akademik Bakış, 8(2), 651-682. 
Tan A. ve Bektaş F. (2002). Otobüs Firmaları İyi Hizmet Pazarlayabiliyorlar mı?. Pazarlama Dünyası, 16(3), 24-27.

Tavmergen, I. P. (2002). Turizm Sektöründe Kalite Yönetimi: Hizmet Kalitesi Kavramı - Kalite Yaklaşımları ve Kalite Geliş̧tirme - Toplam Kalite Yönetimi - Kullanılan Araçlar ve Teknikler, Ankara: Seçkin Yayıncılık.

Ural, A. ve Kılıç, İ. (2006). Bilimsel Araştırma Süreci ve SPSS ile Veri Analizi. Ankara: Detay Yayıncilik.

Ulaştırma ve Altyapı Bakanlığı Karayolları Genel Müdürlüğü, (2020). Tarihçe. https://www.kgm.gov.tr/Sayfalar/KGM/SiteTr/Kurumsal/Tarihce.aspx, (Erişim Tarihi: 05.06.2020).

Yapraklı, Ş. ve Ünalan, M. (2016). Karayolu yolcu taşımacılığında hizmet kalitesinin ölçülmesi ve hizmet kalitesinin müşteri sadakatine etkisi: bir uygulama, Erzincan Üniversitesi Sosyal Bilimler Enstitüsü Dergisi (ERZSOSDE), 9(1): 115-130.

Yılmaz, İ. (2012). Turizm öğrencilerinin karayolu yolcu taşımacıllğ 1 hizmetlerine yönelik algılamaları, Anatolia: Turizm Araştırmaları Dergisi, 23(1): 73-85.

Yükseköğretim Kurumu, (2020). Yükseköğretim Bilgi Yönetim Sistemi, öğretim düzeyine göre öğrenci sayısı. https://istatistik.yok.gov.tr/, (Erişim Tarihi: 04.06.2020). 